\title{
СУДОВИЙ ПРЕЦЕДЕНТ У ПРАВОВИХ НОРМАХ ЗАРУБІЖНИХ КРАЇН: ПОРІВНЯЛЬНО-ПРАВОВА ХАРАКТЕРИСТИКА
}

Дундич Л. В.

Автором статmі запропоновано розглянути вироблені та застосовувані на сучасному етапі підходи окремих правових систем та країн до тлумачення судового прецеденту.

У статmі зазначено, що правова наука за своєю природою є транснаціональною, а тому видане й застосоване в одній країні з тією ж структурою і тими ж традиціями може вплинути на способи тлумачення права в іншій країні, а іноді і привести до оновлення застосування законів. Це значною мірою справедливо для таких країн, як Великобританія, Франція, Німеччина, які часто визначають судову практику багатьох іноземних держав, у яких їх право традиційно розглядається в якості моделі.

У статті розкривається зв'язок тлумачення поняття «судовий прецедент» із пануючою юридичною концепцією в даній державі в окремий проміжок часу. Послідовно досліджується історичний аспект використання судового пре цеденту в юридичній практиці різних країн світу. Автор досліджує практику використання судового прецеденту в державах з унітарною та федеративною формами державного устрою.

Одним із найважливіших аспектів статmі є аналіз підходів суддів різних країн до тлумачення правових норм і договорів, а також щодо трактування поняття «судовий прецедент". У статті наголошується, що вивчення тлумачення судового прецеденту як джерела права в різних країнах, використовуючи метод компаративістики, дозволить збагатити вітчизняну юридичну науку та виробити, осучаснити певні підходи до вказаних питань.

На підставі аналізу закордонного досвіду автором доведено, що судовий прецедент, незважаючи на всі відмінності у підходах різних правових систем, вироблення належної практики його застосування, може бути впроваджено у вітчизняну правову систему.

Ключові слова: судовий прецедент, способи тлумачення, судова практика, правові системи, зарубіжні країни.

Автором статьи предлагается рассмотреть применяемые на современном этапе подходы отдельных правовых систем и стран к толкованию понятия «судебный прецедент».

В статье указано, что правовая наука по своей природе является транснациональной, а потому выданное и примененное в одной стране с той же структурой и теми же традициями может повлиять на способы толкования права в другой стране, а иногда и привести к обновлению применения законов. Это во многом справедливо для таких стран, как Великобритания, Франция, Германия, которые часто определяют судебную практику многих иностранных государств, в которых их право традиционно рассматривается в качестве модели.

Последовательно исследуя исторический аспект использования судебного прецедента в юридической практике различных стран мира, в статье раскрывается связь толкования понятия "судебный прецедент" с господствующей юридической концепцией в данном государстве в отдельный период времени. Автором исследуется практика использования судебного прецедента в государствах

Дундич Л. В., 2019 с унитарной и федеративной формами государственного устройства.

Одним из важнейших аспектов статьи является анализ подходов судей разных стран к толкованию правовых норм и договоров, сравнение их схожих и отличительных черт с толкованием понятия «судебный прецедент». статье подчёркивается, что изучение толкования судебного прецедента как источника права в разных странах, используя метод компаративистики, позволит обогатить отечественную юридическую науку и выработать, осовременить определенные подходы к указанным вопросам.

На основании анализа зарубежного опыта автором доказано, что судебный прецедент, несмотря на все различия в подходах различных правовых систем, выработки надлежащей практики его применения, может быть внедрен в отечественную правовую систему.

Ключевые слова: судебный прецедент, способы толкования, судебная практика, правовые системы, зарубежные страны.

The author of the article proposes to consider the developed and applied at present stage approaches of separate legal systems and countries to interpretation of judicial precedent.

The article states that legal science is transnational in nature, and therefore issued and applied in one country with the same structure and traditions, can influence the way in which law is interpreted in another country and sometimes lead to a renewed application of the law. This is largely true of countries such as the United Kingdom, France, Germany, which often define jurisprudence of many foreign countries where their law has traditionally been considered as a model.

Consistently exploring the historical aspect of the use of judicial precedent in jurisprudence of different countries of the world, the article reveals the connection of the interpretation of the concept of "judicial precedent" with the dominant legal concept in a given state in a separate period of time. The author explores the practice of using judicial precedent in states with unitary and federal forms of government.

One of the most important aspects of the article is analyzing the approaches of judges of different countries to interpreting legal norms and treaties, comparing their similar and distinctive features to interpreting the concept of "judicial precedent". Using the method of comparatives in legal science, the author emphasizes that studying the interpretation of judicial precedent as a source of law in different countries will allow to enrich the national legal science and to develop, to update certain approaches to these issues.

Based on the analysis of foreign experience, the author argues that the judicial precedent, despite all the differences in the approaches of different legal systems, the development of good practice of its application can be implemented in the domestic legal system.

Key words: judicial precedent, methods of interpretation, jurisprudence, legal systems, foreign countries.

Постановка проблеми та їі актуальність. Наукове осмислення судового прецеденту у правових нормах зарубіжних країн неможливо собі уявити без проведення його порівняльно-правової характеристики. Це, 
в першу чергу, сприяє певному розумінню сучасності застосування судового прецеденту та визначенню його практичного значення як способу реалізації правових норм у судовій системі зарубіжних країн.

Водночас застосування судового прецеденту припускає і певний метод тлумачення, важливість якого в наш час неодноразово підкреслювалася доктриною кримінально-процесуального права. У різних країнах пропонувалися найрізноманітніші методи тлумачення та правові доктрини (теоріі) з даного питання. Тому для фундаментального вивчення вироблених підходів до тлумачення поняття «судовий прецедент» вважаємо за доцільне розглянути практики тлумачення права держав, які мають розвинену правову науку, засновану на надбаннях вчених, правознавців та практиків за багато століть. Це однозначно дозволить нам збагатити свої знання в даній царині та глибше зрозуміти сутність досліджуваного явища.

Аналіз останніх досліджень і публікацій. Варто зазначити, що значний внесок у висвітлення поняття «судовий прецедент» у правових нормах зарубіжних країн та судової правотворчості на теренах України зробили такі дослідники, як П. Гук, С. Загайнова, В. Завидняк, О. Константій, Л. Корчевна, М. Кучін, О. Жидков, Б. Малишев, А. Наумов, І. Овчаренко, А. Осетинський, Л. Петрова, О. Скакун, Р. Тополевський, В. Трофименко, С. Шевчук та інші.

Разом з тим наукові надбання та практичні рекомендації більш сучасного періоду іноземних держав (XX-XXI ст.) із вказаної теми ними мало висвітлювалися. Тільки поодинокі роботи таких вчених як М.Г. Дубінін, О.В. Чернецька, В.С. Шилінгов, Є.Н. Тонков, М.А. Матинян, Ю.В. Неділько розглядають сучасний закордонний досвід у сфері інтерпретаційної діяльності.

Саме тому у статті пропонується розглянути вироблені та застосовувані на сучасному етапі підходи окремих правових систем та країн до тлумачення поняття «судовий прецедент як джерело права» $з$ метою сформулювати своєрідні орієнтири нашій державі для впровадження у практику правозастосування та регулювання правовідносин у судовій сфері.

Метою статті $\epsilon$ розгляд сучасних наукових підходів окремих правових систем та країн до тлумачення та застосування судового прецеденту як джерела права.

Виклад основного матеріалу. Варто усвідомлювати, що прагнення людини знайти справедливе рішення у кримінальному провадженні по тій чи іншій справі залежить від психології судді й позиції тієї школи, яку він свідомо або інтуїтивно підтримує.

Тлумачення «судовий прецедент як джерело права» можна назвати вершиною юридичної майстерності й основою в питаннях правозастосування. Перш ніж застосовувати будь-який принцип або норму права в конкретній ситуації, необхідно спочатку його правильно витлумачити [1, с. 131].

У всіх країнах суддя, прагнучи до того, щоб уникнути докорів у свавіллі, віддає перевагу тлумаченню, яке разом з буквою закону враховує й намір законодавця. Це означає, що в переважній більшості випадків суддя проводить логічне (якщо не граматичне) тлумачення, доповнене і підправлене в необхідних випадках зверненням до обставин прийняття відповідних нормативних актів. Але якщо того вимагає справедливість, суддя в будь-якій країні знайде спосіб відставити текст закону, що заважає йому.
Зокрема, французький Касаційний суд не лише контролює спосіб застосування суддями правової норми, але й дає власне тлумачення цієї норми. Таким чином, правова наука за своєю природою $є$ транснаціональною.

Так, наприклад, видане і застосоване в одній країні з тією ж структурою і тими ж традиціями, що у Франції, може вплинути на способи тлумачення права в нашій країні, а іноді і привести до оновлення застосування законів без втручання законодавця. Яскравим прикладом цьому може слугувати той факт, що постанови Касаційного суду або Державної ради Франції часто визначали судову практику багатьох іноземних держав, у яких французьке право традиційно розглядалося в якості моделі.

Це ще більше явно для англомовних країн, де право створюється в основному судами: постанови вищих судів Великобританії часто зумовлюють діяльність австралійських або канадських суддів i, навпаки, за деякими австралійськими або канадськими рішеннями у Великобританії признається авторитет, майже рівний англійським прецедентам.

У деяких сучасних країнах (у Великобританії, більшості штатів США, Канаді, Австралії) судовий прецедент визнається джерелом права й лежить в основі усієї правової системи. Відповідно до пануючої в них доктрини, він не створює норми, а тільки формулює те, що витікає із загальних начал права, закладених у людській природі. У багатьох інших державах судовий прецедент використовують при вирішенні питань застосування права, заповнення прогалин в законі, визнання звичаю; на основі прецеденту вносяться окремі доповнення в чинне законодавство, дається тлумачення закону.

Підходи до вирішення багатьох правових питань у Великобританії $\epsilon$ своєрідні, оскільки ця країна не сприйняла римське право, в якому основне місце займає цивільне право в якості зразка. I саме тому правова система Великобританії не визнає поділу права на приватне і публічне. Також не визнається виділення торгового права із норм цивільного права, як це прийнято у Франції, в Німеччині й багатьох інших країнах. На нашу думку, такий підхід у зарубіжних країнах можна пояснити застосуванням принципу верховенства права [2, с. 350].

У Великобританії на сучасному етапі відносно тлумачення закону не існує суворих канонів. Отже, має бути розвинене певне розуміння, як і якою мірою можна прибігати до того або іншого методу тлумачення, які шанси $\epsilon$ для того, щоб змусити суд змінити судову практику. До речі, як показало дослідження, в цій країні ніколи не говорять про зміну судової практики, а лише про новий розвиток права шляхом застосування техніки виключень.

От чому англійський юрист має володіти саме технічним прийомом у захисті прав і свобод людини в судовому засіданні по суті справи. Саме це дозволяє йому дійти потрібних результатів, не порушуючи самої будови джерела права, подібно до того, як у Франції приймають нові рішення, залишаючи зовні незміненими старі кодекси.

Раніше правило прецеденту дотримувалося надзвичайно суворо відповідно до вимог того часу. Зарубіжні вчені, досліджуючи судовий прецедент, зазначали, що основним шляхом закріплення прецедентного права в Англії стали діяльність колоніальних суддів [3, с. 29], а також можливість рішень вищих національних судових 
органів до Судового комітету Таємної ради [4, с. 98], В іншому випадку суд пристосовуються до вимог епохи, розробляючи нові доктрини і використовуючи техніку виключень.

Нині розвиток права вимагає більшої гнучкості в силу прискореного темпу трансформації сучасного суспільства. На континенті змогли задовольнити ці вимоги, зберігши кодекси, але встановивши гнучкіші методи тлумачення. У Великобританії й сьогодні зберігається правило судового прецеденту, але в тих галузях, де це необхідно. В іншому випадку суд пристосовуються до вимог епохи, розробляючи нові доктрини і використовуючи техніку виключень.

Необхідно підкреслити величезну роль судового прецеденту у правозастосовній практиці судових органів зарубіжних країн, яке дано в попередніх судових рішеннях. Зокрема, право Канади хоча і формувалося під впливом системи англійського загального права, але входить до групи американського загального права. У країні діє основний принцип цієї системи: рішення судів вищого рівня набувають силу судового прецеденту. У наші дні система канадського загального права функціонує як самостійна. Проте зберегли значення й увійшли до складу канадського загального права рішення англійських судів, прийняті раніше в результаті тлумачення чинних в Канаді англійських законів і норм загального права.

В цілому судова практика не $\epsilon$ джерелом права, тому що не $\epsilon$ формою вираження норм права, а лише результатом правозастосування, тлумачення норм, у той час як джерело права $\epsilon$ результатом правотворчості. Дане положення ґрунтовно досліджено юристами англосакської правової системи, які розглядають у якості джерела права саме судовий прецедент, а не судову практику.

Важливість ролі судової практики в сучасному процесі тлумачення підтверджується постійним зростанням кількості збірок судових рішень з різних правових питань у таких країнах континентальної правової сім'ї, як Франція, Німеччина, Швейцарія, Італія та в багатьох інших. Крім того, вищі судові органи в цих країнах регулярно видають акти, що узагальнюють судову практику і тлумачать діючі законодавчі норми з метою їх одноманітного застосування.

Позитивістська теорія, яка вважає, що закон $є$ винятковим джерелом права, здавалося б, безперечно перемогла в різних країнах романо-германської правової сім'ї відразу ж після кодифікації. Ця доктрина і сьогодні часто викладається студентам як загальноприйнята в цих країнах. За кордоном, особливо в країнах загального права, вважають, що вона відповідає практиці. Насправді сталося значне пом'якшення позицій юристів.

Доктрина природного права в наші дні відродилася. Самі прибічники позитивізму відмовилися від розуміння закону таким, яким він представлявся в XIX столітті; зараз вони визнають творчу роль суддів. Ніхто не вважає більше закон єдиним джерелом права і не вважає, що чисто логічне тлумачення закону може в усіх випадках привести до знаходження правового рішення [5, с. 70].

Німецьке право сьогодні не лише наздогнало, але і перегнало французьке право по тій ролі, яку грає в його розвитку, - в усякому разі, у низці галузей судова практика [6]. Наприклад, Федеральний Верховний суд Німеччини вказав, що при створенні закону суб'єкт правотворчості не обмежує його дію конкрет- ними, заздалегідь планованими випадками, тому що нормативний акт $\epsilon$ не «мертвою буквою», а «живим духом», що розвивається, пристосовується до життєвих умов, і ця адаптація $\epsilon$ корисною до тих пір, поки не виходить за рамки закону.

Проте варто зазначити, що в німецькій юридичній науці не визначене конкретне співвідношення різних прийомів і методів тлумачення, хоча ця обставина не означає, що тлумачення має бути довільним. Коли різні аргументи тлумачення конкурують, треба віддавати перевагу тим, які приводять до висновків, що відповідають основному змісту закону й вимогам справедливості. Отже, можна констатувати, що в Німеччині судовий прецедент, його телеологічне тлумачення $\epsilon$ вирішальним чинником у виключенні сумнівів при прийнятті рішення по суті справи.

Італія, де панує яскраво виражена догматична тенденція, поза сумнівом, нині ще далі від практикованих у Франції гнучких методів тлумачення. Розрив між викладанням права і судовою практикою, що існує в цій країні, ускладнює розуміння іноземцями того, як судді і практики Італії тлумачать свої закони. Аналогічні зауваження можна зробити відносно іспанського і португальського права, а також права країн Латинської Америки. Тут також сильні традиційні установки і своє головне завдання судді бачать у справедливості рішення, хоча в багатьох теоретиків цих країн в шані ті течії політичної філософії, які підкреслюють роль закону.

Отже, як свідчить аналіз систем права в різних країнах та правових системах, судова практика не виступаючи офіційно визнаним джерелом права, все ж має велике значення, особливо у процесі тлумачення, оскільки може фактично змінювати положення закону і встановлювати зміст загальних принципів права.

Важливим при вивченні тлумачення судового прецендента як джерела права $\epsilon$ також питання про те, наскільки інтерпретацією змінений зміст норми. У зв'язку з цим європейські дослідники тлумачення судового прецендента як джерела права дотримуються двох концепцій [7]:

- скептична - суть норми визначає інтерпретатор;

- формальна - завдання інтерпретатора полягає у скрупульозному встановленні істинного сенсу норми, закладеного в ній законодавцем (отже, сенс норми виник до ії тлумачення, і розкривається лише шляхом правильної інтерпретації).

Цікавим у рамках тематики дослідження буде розгляд реформування в галузі цивільного права Франції. Так, у 2016 році у Франції через 212 років провели кардинальне реформування норм зобов'язального й договірного права в Кодексі Наполеона. До речі, французи кардинально переписали своє договірне і зобов'язальне право, наблизивши його до німецького права і змісту загальноєвропейських актів уніфікації права (PECL, DCFR) [8]. Це дозволило законодавцю у процесі реформування судової системи включити напрацювання судової практики за багато років і водночас зробити власне право більш гнучким, справедливим і ефективним, а отже привабливим в умовах зростаючої конкуренції європейських юрисдикцій.

3 огляду на проведені реформи стало актуальним питання, як відрізнити імперативні норми від норм диспозитивних в положеннях Цивільного кодексу Франції про зобов' язання й договори. Розробники віддали пере- 
вагу традиційній для європейського права методології відмові від чіткого текстуального позначення більшості норм в якості імперативних або диспозитивних.

У низці найбільш очевидних випадків в тексті прямо говориться про те, що заборонено домовлятися про щось, а іноді зазначається, що сторони мають право погоджувати умову, відмінну від записаного в законі. Але такі підказки зустрічаються в незначній кількості випадків. У переважній більшості нових норм просто закріплюються ті або інші права й обов'язки сторін без чіткої ідентифікації природи норми.

Відповідно до сталої традиції, природа таких норм вважається не конкретизованою в законі, і це завдання суддів шляхом телеологічного тлумачення визначити їх імперативну або диспозитивну природу [9, с. 332]. Загальна ідея така: за загальним правилом норми договірного права $\epsilon$ диспозитивними (із загального принципу договірної свободи - все, що прямо не заборонено, то дозволено), який у Франції має конституційне значення. Але суди можуть при тлумаченні дійти висновку і про імпліцитну імперативність відповідної норми, якщо на його погляд мета норми полягає в обмеженні договірної свободи.

Отже, можна констатувати, що розробники вирішили не відступати від укоріненої методології, заснованої на судовому телеологічному тлумаченні природи норм договірного права, вважаючи недоцільним закріпити в законі чітко, які норми імперативні, а які диспозитивні.

Характеризуючи процес тлумачення у Сполучених Штатах Америки, слід враховувати, що діє компетенція не федеральної влади, а кожного із штатів. При цьому система права у різних штатах має багато відмінностей, які переважно пов'язані із законодавчими рішеннями, але бувають і наслідком тлумачення загального права. Значні відмінності по штатах має судова система, цивільний і кримінальний процес (наприклад, підстави і умови розлучення, спільність та роздільність майна подружжя, відмінності у праві товариств і таке інше).

Проте слід зазначити, що Верховний суд США суттєво змінив конституційне розділення повноважень між федерацією і штатами шляхом тлумачення формул конституційного тексту і поправок. Зокрема Штати зобов'язали поважати деякі загальні принципи, як на законодавчому рівні, так і в судовій практиці [10, с. 125].

Слід підкреслити схожість підходів англійських і американських юристів тому, що право - це передусім судова практика, а норми закону входять у систему права лише після того, як неодноразово застосовані і представлені суддями. В американських судах, також як і в англійських, перевагу віддають посиланню не на закони, а на судові рішення, де вони застосовані.

Проаналізувавши закордонний досвід щодо тлумачення судового претендента як джерела права, варто звернути увагу на позицію вітчизняного вченого В. Завидняка, який досліджуючи впровадження судового прецеденту в Україні, дійшов висновку, що правотворчість у формі судових прецедентів $\epsilon$ безперервним процесом. 3 одного боку, суддя не йде наосліп за своїми попередниками, він може розвивати право. 3 іншого - дії судді з розвитку права мають відповідати системі вже створених його попередниками норм і зберігати внутрішню узгодженість з ними [11, с. 61]. Це ще раз підкреслює фундаментальність цієї тематики: незважаючи на всі відмінності в підходах різних правових систем, усіх їх об'єднує одна мета: вироблення належної практики застосування правових норм через правильне розуміння та роз'яснення правових приписів.

Висновки. Сучасний глобальний світ характеризується тісною взаємодією та взаємним проникненням, особливо в інтелектуальну сферу, комунікації, а тому не можна не знати й не вивчати інший позитивний успішний досвід у різних сферах знань про судовий прецедент як джерело права. Саме з'ясування специфіки судового тлумачення судового прецеденту як джерела права в різних країнах дозволить збагатити вітчизняну юридичну науку та виробити, осучаснити певні підходи до вказаних питань як осіб, що застосовують право, так і осіб, які творять нові закони та потребують подальшого розгляду та вивчення.

\section{Література}

1. Дубинин М.Г. Толкование права в романо-германской и англосаксонской правовых семьях (на примере ФРГ и Великобритании). Вестник Нижегородского университета имени Н.И. Лобачевского. Серия «Право». 2015. № 3. - С. 131-137.

2. Чернецька О.В., Шилінгов В.С. Право Англії як класична модель прецедентного права. Правова система України й міжнародне право, порівняльне правознавство. 2015. № 4. С. 348-352.

3. Жидков О.А. Судовой прецедент в правовых системах развивающихся стран. Источник права. М. : Наука, 1995. С. 28-46.

4. Малишев Б. Судовий прецендет у правовій системі Англії (теоретико-правовий аспект) : дис кандидата юрид. наук : 12.00.01. К., 2002. 229 с.

5. Лярская Н.С Воздействие Институциональной среды на формирование Государственной модели корпоративного управления. Экономический вестник Ростовского муниципального института. 2006. Том 4. № 2. С. 70-88.

6. Cecile Perez "Mandatory and Non - Mandatory Rules in the New Law of Contract". // "The Code Napoléon Rewritten : French Contract Law after the 2016 Reforms". Studies of the Oxford Institute of European and Comparative Law) 1st Edition, Kindle Edition. - 2017. - 536 p. Gunter Wesener: Paul Koschaker (1879-1951), Begründer der altorientalischen Rechtsgeschichte und juristischen Keilschriftforschung, in: Karl Acham (Hrsg.): Rechts-, Sozialund Wirtschaftswissenschaften aus Graz, Wien/Köln/Weimar 2011, S. 273-285.

8. Principles, Definitions and Model Rules of European Private Law. Draft Common Frame of Reference (DCFR). Prepared by the Study Group on European Civil Code and the Research Group on EC Private Law (Acquis Group). Based in part on a revised version of the Principles of European Contract Law. - 4795 p.

9. Антонов М.В. Современная теории права во Франции: реалистический подход к праву в концепции Мишеля Тропера и спор о неореализме в толковании. Российский ежегодник теории права. 2012. № 4. С. 321-345.

10. Тонков Е.Н. Толкование закона в Англии. М. : Издательство «Алетейя», 2013. 356 с.

11. Завидняк В.І. Впровадження судового прецеденту у кримінальний процес України. : монографія. Ірпінь. Університет ДФС України. 2019. 410 с.

Дундич Л. В., кандидат юридичних наук, доцент кафедри професійних та спеціальних дисциплін Херсонського факультету Одеського державного університету внутрішніх справ 